\title{
Study on the Investigation of the Fatigue Behavior of Engineered Cementitious Composites with High Tenacity Polypropylene (HTPP) Fibers
}

\author{
Mert Tatarca' (iD) Burak Felekoglu' (iD) Eren Godek ${ }^{2}$ (D) \\ ${ }^{1}$ Dokuz Eylul University, Department of Construction Materials, Izmir, Turkey \\ ${ }^{2}$ Hitit University, Department of Construction Technology, Corum, Turkey
}

\section{ABSTRACT}

I Th this study, the fatigue behavior of Engineered Cementitious Composites incorporating
high tenacity polypropylene fiber was investigated. The strain curves, cycle numbers,
crack numbers and stiffness values were obtained from the experiments carried out with
the load-controlled fatigue method at 80,90 and $110 \%$ stress level (maximum stress/ul-
timate static strength). In conclusion, at $80 \%$ stress level, average 1127 cycles, $1.37 \%$ the
unit deformation capacity and 6 cracks were achieved. At $90 \%$ stress level, 215 cycles,
$1.89 \%$ the unit deformation capacity and 8 cracks were obtained. In the specimens where
$110 \%$ stress level was applied, the average number of cycles was decreased to 38 cycles, the
unit deformation capacity increased up to $2.60 \%$ and the average number of cracks also
doubled and raised to 15 cracks. Additionally, the average stiffness values of 8.68 and 9.57
GPa were obtained in the first cycles at $80 \%$ and $90 \%$ stress levels, it was observed that
the stiffness values gradually decreased with increasing cycles. Although high strain values
were achieved at the $110 \%$ stress level, micro cracks were formed suddenly due to the very
high applied loading and the rigidity values remained low since the first cycle due to the
plastic deformation.

Keywords: HTPP fiber, ECC, Fatigue, Cyclic loading, Secant modulus

\author{
Article History: \\ Received: 2020/12/20 \\ Accepted: 2021/03/31 \\ Online: $2021 / 06 / 30$
}

Correspondence to: Mert Tatarca, E-mail:merttatarca@windowslive.com;

Phone: +905542932411

\section{INTRODUCTION}

—atigue is a complex thermic and mechanical incident - which can result thaw, wear and decomposition occurring in the materials due to repetition of loads and unloads, periodically [1]. Especially in some structures, which exposed to loads such as traffic, thermal changing, winds, sea waves and earthquakes, the rigidity of the structures decrease and collapse [2]. Construction materials can lose their strength when loaded periodically with sufficient repetition between two specified limit values of loads even the loads below their load bearing capacity.

In general, there are two basic loading methods to investigate of fatigue behavior of materials. First method is load controlled method that based on stress level and most common method (Fig. 1a). The other method is called deformation controlled method that facilitates particular analysis of stress and strain in local areas (Fig. 1b) [3]. Additionally, fatigue loads are separated to two parts as low cyclic and high cyclic loading. Low cyclic loading is defined by loading at a high stress level and making a small number of cycles. On the other hand high cyclic loading is characterized by loading at the low stress level and making lots of number of cycles [4].

Concrete is one of the most used construction material today. During various loading conditions, a crack is formed at the cross section of concrete which reached to load bearing capacity. This cause to lose entire load bearing capacity of concrete rapidly without using all mass of concrete. Due to this situation, it is become very common that usage of macro or micro fiber into the concrete which in order to prevent abrupt collapse failure and much more take advantage of mass of concrete [5]. Poor performance of plain concrete under cyclic loading has been reported by various researchers $[6,7]$ By using these kinds of fibers, it is possible to enhance mechanical performance of concrete under fatigue loading [8]. Many fiber types are adopted to cement-based composites due to the developed concrete technology. 


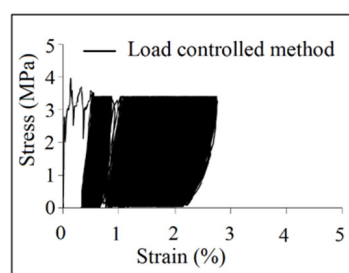

(a)

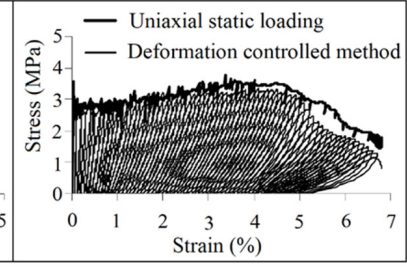

(b)
Figure 1. The typical demonstrations for a) Load controlled method; b) Deformation controlled method.

Substitution of the steel fibers into concrete, which are the first advanced fibers of modern times, increase load bearing capacity, crack growth resistance and fatigue strength $[4,9]$. In recent years, cement-based composites which are produced with using fibers such as poly-vinyl alcohol (PVA) high tensile polypropylene fibers (HTPP) and polyethylene (PE), are considered that will indicate superior performance under the fatigue loading [10]. These composites which demonstrate high ductility and toughness under tensile, flexural and shear loading owing to strain-hardening behavior, are called ECC (Engineered Cementitious Composites). High toughness and ductility feature of these composites are provided by their multiple cracking behaviors. Owing to this behavior, ECC demonstrate strain-hardening unlike plain and conventional fiber reinforced composites [11]. After the first crack is occurred at the weakest section of the composites, loads mentioned upward which cause propagation of crack abruptly, are held by fibers and transmitted to the other uncracked sections of matrix. Then, additional cracks occur in the sections where the load is transferred. This repetitive event prevents sudden collapse and achieve deformation hardening behavior and energy absorption capacity of composites rises considerably when compared to plain composites [12]. There are studies showing that the performance of these polymeric fiber reinforced composites can also be increased under fatigue loads. Mechtcherine and June (2007) studied the fatigue behavior of PVA-ECC under load controlled method and deformation controlled method. Under the fatigue loading, secant modulus of composites was calculated and change of rigidity of these composites were investigated in addition to cycle and cracks numbers. When the hysteresis curves were examined, it was observed that composites had high stiffness values at low deformation values in the initial cycles. Decreases in stiffness values were also observed with expanding hysteresis curves and increasing deformation values as the number of cycles increased [13]. Another study conducted by Sui (2018), compared the fatigue performance of PVA-ECC and PE-ECC under flexural loading at the rates of 50\%, 65, 80 and 90 of the flexural strength under static loading. Due to the inability of fibers to be actively used under low fatigue loading of ECC and because fatigue loads are mostly carried by the matrix at low fatigue loading, less crack numbers and deformation values were obtained. With the increase in the stress level, the fibers being more active and the ability to make multiple cracks give more favorable results in terms of fatigue life and reach high deformation capacities [14].

Nowadays, there are abundant studies conducting with PVA or PE fibers composites [15-19]. The commonly used fiber type in the literature is mostly PVA. Last decade, ECC produced with HTPP fiber (HTPP-ECC), which are considered as new generation polymeric fibers, has growing interest. HTPP-ECC differs from PVA-ECC due to fiber and fiber-matrix interaction properties. There are studies on the flexural and tensile performances of HTPP-ECC $[5,20]$. However, fatigue performance of HTPP-ECC under flexural and tensile stress has been investigated, rarely. Jin and Li (2019) has investigated fatigue performance of HTPP-ECC which used on wind turbine tower under 4-point flexural loading at 70, 80 and $90 \%$ of their static strength and it was reported that fatigue life of HTPP-ECC was 50 times longer compared to plain concrete [21].

Apart from the study which mentioned upward, it is seen that there is not enough research on the fatigue behavior of HTPP-ECC. In order to fill this gap and to contribute to the literature, fatigue performance of HTPP-ECC under different stress levels has been investigated within the scope of the study. For this purpose, dog-bone shaped tensile specimens were produced and they were subjected to tensile fatigue loading at 80,90 and $110 \%$ of tensile strength. Thus, it was planned to better understand the low cycle dynamic effects at the high stress value as earthquake loads and examine the correlation between deformation ability and cycle capacity of ECCs at the different stress levels. In addition to this, it was aimed to contribute to literature by examining fatigue life and stiffness changes of composites.

\section{MATERIAL AND METHODS}

Within the scope of the experimental program, previously designed matrix adopted from the study that it is compatible with HTPP fiber [20]. The water/cement ratio of the mixture was 1.10 and powder material/cement ratio was 2.5. The composites were labelled as HCF and mixture ratios were presented in Table 1. CEM I $42.5 \mathrm{R}$ type cement and Granulated Blast Furnace Slag (GBFS) were used. Chemical, physical and mechanical properties of the cement is shown at Table 2 .

Chemical and physical properties of GBFS is shown in Table 3. HTPP fibers were used in fiber phase of the mixture. Physical and mechanical properties of HTPP fibers are shown at Table 4.

The volume of the mixture was determined as $4 \mathrm{dm}^{3}$ for pouring process. In mixing process laboratory type Ho- 
bart mixer was used. Cement and GBFS were mixed for 3 minutes, then water was added and mixed for another 3 minutes. After that, HTPP fibers by $2 \%$ of total mixture volume was added to the mixture and superplasticizer additive was added in order to distribute the fibers homogeneously to the whole matrix and the mixing process was continued for 3 more minutes. 12 samples were taken into dog-bone shaped steel molds. The dimensions of molds were shown in Fig. 2, which were manufactured in accordance with the recommendation of the Society of Japanese Civil Engineers [22]. After the specimens stayed for two days in molds, they removed and stayed for 28 days in lime-saturated curing pool at $20 \pm 2^{\circ} \mathrm{C}$.

Shimadzu branded tensile tester was used for measurement of fatigue performance of the specimens under tensile fatigue tests. The device has $50 \mathrm{kN}$ load capacity and capable of repeated loading at $0.05 \mathrm{~Hz}$ with three cycles per minute,

Table 1. Mixture ratio of HCF.

\begin{tabular}{cccccc}
\hline Ingredients & Cement & $\begin{array}{c}\text { Granulated } \\
\text { Blast } \\
\text { Furnace } \\
\text { Slag }\end{array}$ & Water & $\begin{array}{c}\text { Super- } \\
\text { plasticizer }\end{array}$ & HTPP fiber \\
\hline $\mathrm{kg} / \mathrm{m}^{3}$ & 424 & 1059 & 466 & 8 & 18 \\
\hline
\end{tabular}

Table 2. Chemical, physical and mechanical properties of the CEM I 42.5 R cement.

\begin{tabular}{|c|c|c|c|c|c|c|c|c|}
\hline \multicolumn{9}{|c|}{ Chemical Analysis (\%) } \\
\hline $\mathrm{SiO}_{2}$ & $\mathrm{Al}_{2} \mathrm{O}_{3}$ & $\mathrm{Fe}_{2} \mathrm{O}_{3}$ & $\mathrm{CaO}$ & $\mathrm{MgO}$ & $\mathrm{Na} 2 \mathrm{O}$ & $\mathrm{K} 2 \mathrm{O}$ & $\mathrm{SO}_{3}$ & $\mathrm{Cl}-$ \\
\hline 18.57 & 4.95 & 3.11 & 63.94 & 0.98 & 0.37 & 0.75 & 3.07 & 0.006 \\
\hline \multicolumn{9}{|c|}{ Mechanical and Physical Properties } \\
\hline Comp & $\begin{array}{r}\text { ressive } \\
(\mathrm{MPa})\end{array}$ & $\begin{array}{l}\text { trength } \\
28 \text { days }\end{array}$ & $\begin{array}{l}\text { Specific } \\
\text { gravity } \\
\left(\mathrm{g} / \mathrm{cm}^{3}\right)\end{array}$ & $\begin{array}{l}\text { Specific } \\
\text { surface } \\
\left(\mathrm{cm}^{2} / \mathrm{g}\right)\end{array}$ & $\begin{array}{c}\text { Residue } \\
\text { on } \\
\text { o.ogo } \\
\text { mm } \\
\text { sieve } \\
(\%)\end{array}$ & $\begin{array}{l}\text { Residue } \\
\text { on } \\
0.045 \\
\text { mm } \\
\text { sieve } \\
(\%)\end{array}$ & $\begin{array}{l}\text { Soun } \\
\quad(m\end{array}$ & $\begin{array}{l}\text { Iness } \\
\text { n) }\end{array}$ \\
\hline 27.2 & 39.9 & $49 \cdot 3$ & 3.09 & 3370 & 0.7 & $19 \cdot 3$ & 0 . & \\
\hline
\end{tabular}

Table 3. Chemical and physical properties of Granulated Blast Furnace Slag.

\begin{tabular}{|c|c|c|c|c|c|c|}
\hline \multicolumn{7}{|c|}{ Chemical Analysis (\%) } \\
\hline $\mathrm{SiO}_{2}$ & $\mathrm{Al}_{2} \mathrm{O}_{3}$ & $\mathrm{Fe}_{2} \mathrm{O}_{3}$ & $\mathrm{CaO}$ & $\mathrm{MgO}$ & $\mathrm{SO}_{3}$ & $\mathrm{Cl}-$ \\
\hline 39.98 & 11.06 & 0.77 & 32.95 & 10.26 & 0.34 & 0.0075 \\
\hline \multicolumn{7}{|c|}{ Physical Properties } \\
\hline \multicolumn{2}{|c|}{ Ignition loss (\%) } & $\begin{array}{l}\text { Specific } \\
\text { gravity } \\
\left(\mathrm{g} / \mathrm{cm}^{3}\right)\end{array}$ & $\begin{array}{l}\text { Specific } \\
\text { surface } \\
\left(\mathrm{cm}^{2} / \mathrm{g}\right)\end{array}$ & $\begin{array}{c}\text { Residue on } \\
\text { o.ogo } \mathrm{mm} \text { sieve } \\
\text { (\%) }\end{array}$ & \multicolumn{2}{|c|}{$\begin{array}{c}\text { Residue on } \\
0.045 \mathrm{~mm} \text { sieve } \\
\text { (\%) }\end{array}$} \\
\hline \multicolumn{2}{|c|}{2.34} & 2.87 & 5500 & 0 & \multicolumn{2}{|c|}{0.40} \\
\hline
\end{tabular}

Table 4. Physical and mechanical properties of HTPP fibers.

\begin{tabular}{ccccccc}
\hline $\begin{array}{l}\text { Specific } \\
\text { gravity } \\
\left(\mathrm{g} / \mathrm{cm}^{3}\right)\end{array}$ & $\begin{array}{c}\text { Diameter } \\
(\mu \mathrm{m})\end{array}$ & $\begin{array}{c}\text { Length } \\
(\mathrm{mm})\end{array}$ & $\begin{array}{c}\text { Fiber aspect } \\
\text { ratio }\end{array}$ & $\begin{array}{c}\text { Tensile } \\
\text { strength } \\
(\mathrm{MPa})\end{array}$ & $\begin{array}{c}\text { Modulus of Elongation } \\
\text { elasticity } \\
(\mathrm{GPa})\end{array}$ & $\begin{array}{c}\text { at failure } \\
(\%)\end{array}$ \\
\hline 0.91 & 12 & 10 & 833 & 850 & 6 & 21 \\
\hline
\end{tabular}

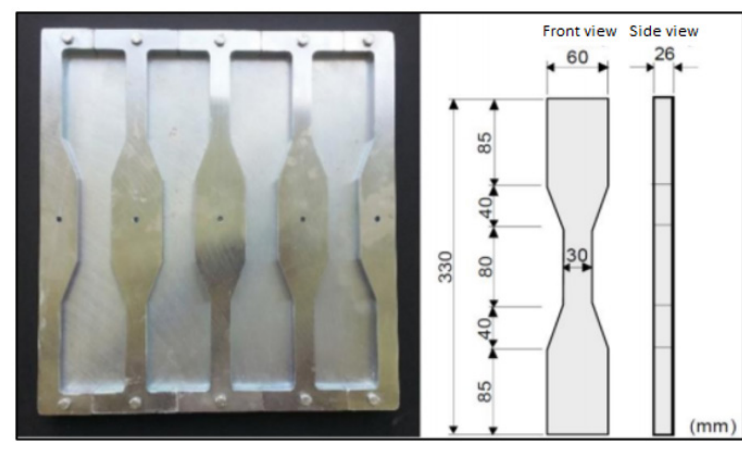

Figure 2. Dog-bone shaped steel molds [22].

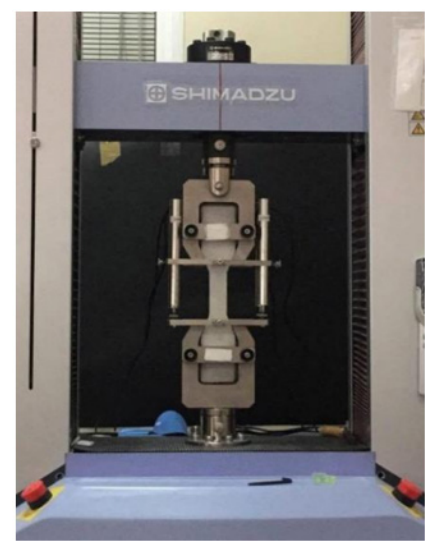

(a)

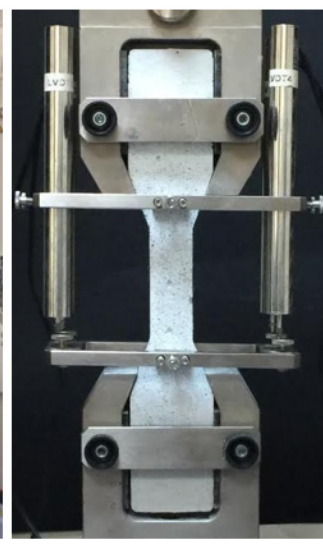

(b)
Figure 3. a) Laboratory countertop type tensile test machine, b) tensile test setup.

load measurement accuracy $\pm 1 \%$ between $1 / 1$ and $1 / 1000$ of the load cell capacity, vertical test area $1250 \mathrm{~mm}$, horizontal test area (between columns space) is $500 \mathrm{~mm}$ countertop type (Fig. 3a). The bottom of the tensile mechanism has embedded, the upper side has jointed pin configure and it is allowed to apply of uniaxial tensile load to specimens. In order to measure displacement of the specimens during the test, four extensometers were used (Fig. 3b).

3 specimens from the prepared twelve specimens, exposed to static tensile test for the determination of tensile strength and unit deformation. The uniaxial tensile test carried out with speed of $0.5 \mathrm{~mm} / \mathrm{min}$. Tensile strengths were calculated by dividing the maximum stress to crosssectional area of the composite and corresponding strain value to the maximum stress was determined as unit deformation. Remaining nine specimens exposed to load controlled fatigue test at the stress levels of $80 \%, 90$ and 110 of the tensile strength. During the test, frequency was set up constantly $0.05 \mathrm{~Hz}$ so as to each last take 20 seconds. After the fatigue failure tests were ended, the stress-strain curves of the specimens were drawn and the number of cycles were determined. The secant modulus values at 1., 10., 100., 1000. and the last cycle were computed as shown at Fig. 4 and the change of secant modulus values were investigated. In the equation, $\mathrm{E}_{\text {sec }}:$ Secant modulus, $\sigma_{\max }:$ Maximum applied 


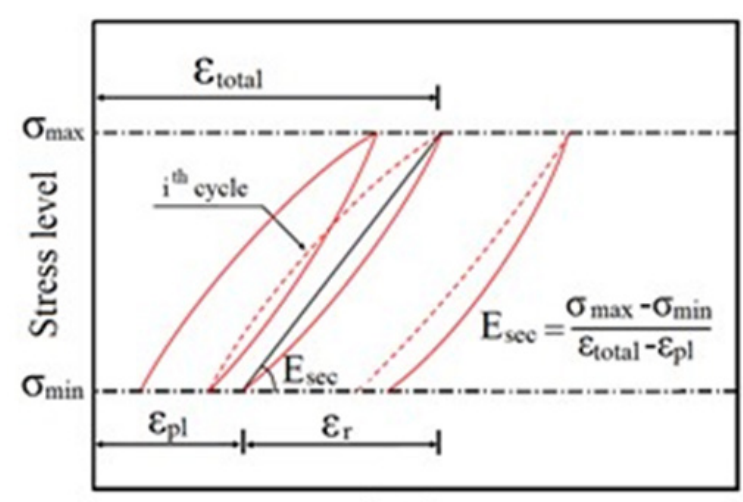

Strain

Figure 4. Computing method of change of the secant modulus [23].

stress, $\sigma_{\min }:$ Minimum applied stress, $\varepsilon_{\text {total }}:$ Total strain, $\varepsilon_{\mathrm{pl}}$ : Sum of plastic strain, $\varepsilon_{\mathrm{r}}$ : Recoverable strain. Finally, fatigue life graphs were drawn by the data obtained from stressstrain curves.

\section{RESULTS AND DISCUSSION}

\section{Uniaxial Static Tensile Test Results}

Uniaxial static tensile tests were executed on 3 specimens, in order to determine the tensile strength of composites. The stress-strain curves were shown in Fig. 5, maximum stress and corresponding unit deformation values that obtained from these curves, are given Table 5. The average tensile strength and the average unit deformation values of 3 specimens were determined as $3.05 \pm 0.06 \mathrm{MPa}$ and $3.84 \pm 0.54 \%$, respectively.

\section{Fatigue Test Results}

The stress-strain curves of cyclic loadings were given in Fig. 6. The applied stress, the unit deformation values, the number of cycles and cracks were calculated by using the curves and given in Table 6. On the graphs, 1., 10., 100., 1000. and the last cycles of specimens are demonstrated different colors and at this cycles, rigidity changes $\left(\mathrm{E}_{\mathrm{sec}}\right.$

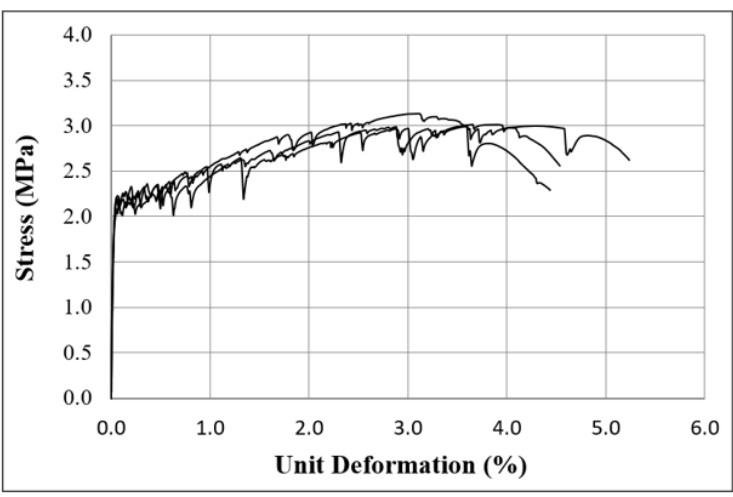

Figure 5. The stress-strain curve of uniaxial static tensile tests.

Table 5. The results of the uniaxial static tensile tests.

\begin{tabular}{ccc}
\hline Specimen & $\begin{array}{c}\text { Ultimate tensile static } \\
\text { strength }(\mathrm{MPa})\end{array}$ & Tensile static strain (\%) \\
\hline HCF-1 & 2.99 & 4.45 \\
HCF-2 & 3.13 & 3.12 \\
HCF-3 & 3.02 & 3.96 \\
Average & $3.05 \pm 0.06$ & $3.84 \pm 0.54$ \\
\hline
\end{tabular}

values) of the specimens have been calculated which is goingto to be discussed in the next section (Fig.7).

When the graph at $80 \%$ stress level was examined (Fig. $6 a)$, it was observed that the specimens exhibited average 1127 cycles, $1.27 \%$ unit deformation value and 6 cracks before the collapse failure (Table 6). When fatigue loading was increased to $90 \%$ stress level, the average number of cycles decreased to 215 and the unit deformation value increased to $1.89 \%$ (Fig. 6b; Table 6). There was no significant change in the average number of cracks, the average number of cracks was determined to be 8 . In the series where the highest stress level was applied (110\%), the specimens exhibited an average of 38 cycles despite being exposed to dynamic loading at a level above the static strength, and the average

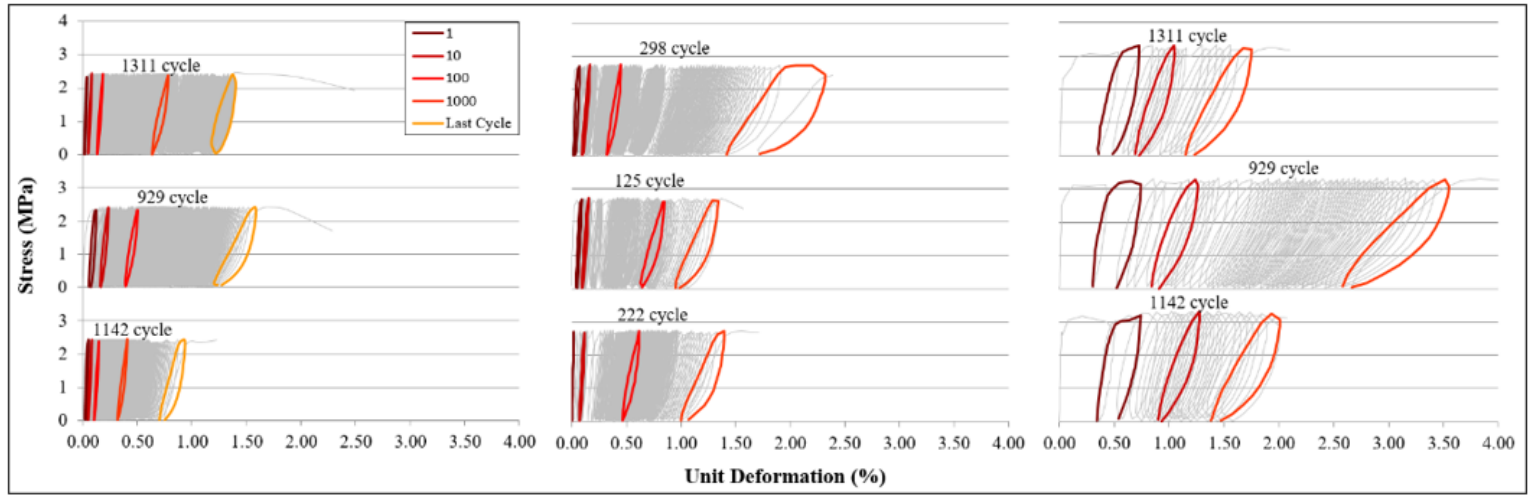

(a)

(b)

(c)

Figure 6. Fatigue tests graphs applied at the different stress levels a) $80 \%$, b) $90 \%$, c) $110 \%$. 
Table 6. Fatigue test results obtained at 80,90 and $110 \%$ stress levels.

\begin{tabular}{lcccc}
\hline Specimen & $\begin{array}{c}\text { Applied stress } \\
(\mathrm{MPa})\end{array}$ & $\begin{array}{c}\text { Unit } \\
\text { deformation } \\
(\%)\end{array}$ & $\begin{array}{c}\text { Cycle } \\
(\mathrm{N})\end{array}$ & $\begin{array}{c}\text { Crack number } \\
(n)\end{array}$ \\
\hline HCF80-1 & 1.01 & 1142 & 5 \\
HCF80-2 & 2.435 & 1.72 & 929 & 5 \\
HCF80-3 & 1.40 & 1311 & 7 \\
Average & $1.37 \pm 0.29$ & $1127 \pm 156$ & 6 \\
HCF90-1 & 1.71 & 222 & 9 \\
HCF90-2 & 2.740 & 2.07 & 125 & 7 \\
HCF90-3 & & 2.53 & 298 & 9 \\
Average & & $1.89 \pm 0.46$ & $215 \pm 71$ & 8 \\
HCF110-1 & & 1.92 & 19 & 13 \\
HCF110-2 & 3.350 & 2.07 & 27 & 18 \\
HCF110-3 & & 3.83 & 67 & 15 \\
Average & & $2.60 \pm 0.86$ & $38 \pm 21$ & 15 \\
\hline
\end{tabular}

number of cracks doubled and reached to 15 (Fig. 6c; Table

6). Compared to other series, the significant increase in multiple cracking behavior increased the unit deformation value of the samples to an average of $2.60 \%$.

\section{Secant Modulus Results}

Within the scope of the study, the changes of secant modulus $\left(\mathrm{E}_{\mathrm{sec}}\right)$ were calculated and given in Fig. 7. At the $80 \%$ and $90 \%$ stress levels, the change of $\mathrm{E}_{\mathrm{sec}}$ values were found to be similar to each other's. At the beginning, both series exhibited high $\mathrm{E}_{\text {sec }}$ values however these values decreased by increased number of cycles. It was determined that average number of cycle was 1127 at the $80 \%$ stress level and 215 at the $90 \%$ stress level. Although high unit deformation values were achieved in the samples exposed to $110 \%$ stress level, the $\mathrm{E}_{\text {sec }}$ values were calculated remarkably low when compared to 80 and $90 \%$. The reason for this is thought to be the early micro cracking as a result of the relatively high dynamic loading. With the triggering of multiple crack mechanism, the rapid increase in the number of micro cracks in a short time caused high plastic deformation in the samples (Fig.7). This situation caused the $\mathrm{E}_{\text {sec }}$ values to remain at lower values compared to the other series since the first cycle.

The stress-cycles to failure graph $(\mathrm{S}-\mathrm{N})$ is presented in Fig. 8. As expected, the number of cycles to failure gradually increased with decreased stress level. Also, there was a strong correlation with a correlation coefficient of $R=0.99$.

\section{CONCLUSION}

In this study, the fatigue performance of HTPP-ECC has been investigated at 80, 90 and $110 \%$ stress levels by load controlled method. The results are given below:

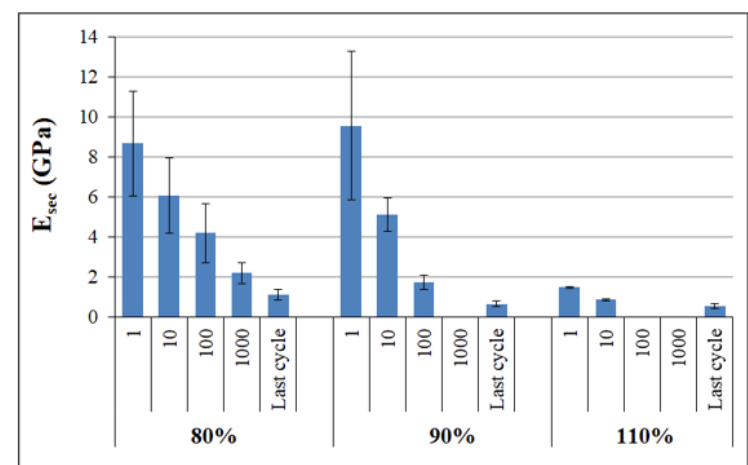

Figure 7. The graph of secant modulus changes of HTPP-ECCs at the different stress level.

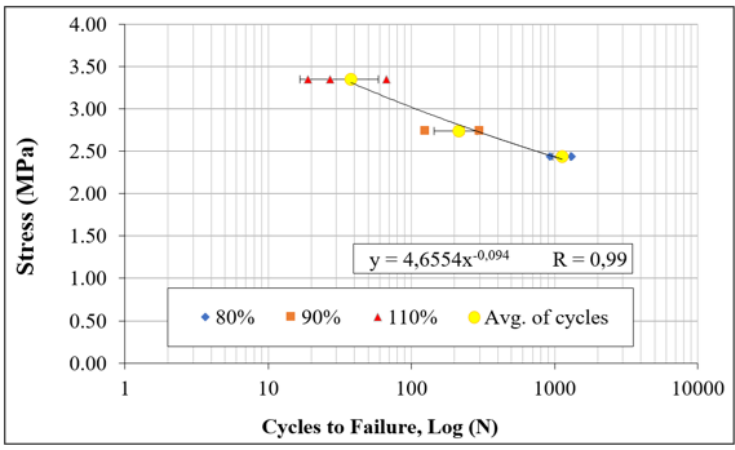

Figure 8. The stress-cycles to failure graphs (S-N) obtained from at 80, 90 and $110 \%$ stress level values.

- As a result of the static tensile test, the composites exhibited an average tensile strength of $3.05 \pm 0.06 \mathrm{MPa}$ and an average unit deformation of $3.84 \pm 0.54 \%$. By using HTPP fibers in the production of ECC has increased both the tensile strength and unit deformation when compared to conventional cement-based composites.

- When the number of cycles performed at three stress levels are examined, it is seen that high cycle numbers are reached at low stress level. With the increase in the stress level, decrease in the number of cycles were observed due to the higher tensile stress value the material is exposed to.

- The most valuable part of this study as a contribution to the literature is that HTPP-ECC have reached an average of 38 cycles, although it is loaded with a stress much higher than its tensile strength ( $110 \%$ stress level). It is thought that the reason for this is that the fatigue loading speed is faster than the static tensile loading speed, so the HTPP fibers in the composite take a much more active role and can withstand considerable cycles at these levels with the feature of more active multiple crack behavior.

- The secant modulus $\left(\mathrm{E}_{\mathrm{sec}}\right)$ of the samples loaded at $80 \%$ and $90 \%$ stress levels were obtained higher, initially. However, these values gradually decreased as the number of cycles increased. Although high strain values were reached 
in the samples exposed to a fast loading above the capacity with $110 \%$ stress level, the secant modulus values remained lower when compared to 80 and 90\% stress level. This phenomenon can be explained by the fact that the relatively high dynamic loading triggers the multiple crack mechanism early and the rapid increase in the number of micro cracks in a short time causes high plastic deformation in the samples.

\section{CONFLICT OF INTEREST}

Authors approve that to the best of their knowledge, there is not any conflict of interest or common interest with an institution/organization or a person that may affect the review process of the paper.

\section{AUTHOR CONTRIBUTION}

Mert Tatarca designed and carried out the experiments. Mert Tatarca and Eren Gödek researched literature, analyzed the data and wrote the manuscript. Burak Felekoğlu supervised the study and helped with the review process of the final manuscript.

\section{References}

1. Baradan B. Material Information for Civil Engineers, Dokuz Eylul University Faculty of Engineering Press, Izmir, Turkey, 2011 (in Turkish)

2. Müller $\mathrm{S}$, Mechtcherine V. Fatigue behaviour of strainhardening cement-based composites (SHCC). Cement and Concrete Research 92 (2017) 75-83.

3. Alam BA. Fatigue performance of engineered cementitious composites. Doctoral Dissertation, Middle East Technical University, Ankara, Turkey, 2016.

4. Paranjape AS. The flexural fatigue performance of high volume synthetic fiber reinforced concrete. Master of Applied Science, Dalhouse University, Nova Scotia, Canada, 2007.

5. Gödek E. Development of practical polymeric fiber reinforced cementitious composites. Master's Thesis, Dokuz Eylül University Institute of Science in Civil Engineering, Izmir, Turkey, 2016 (in Turkish)

6. Forgeron, DP. The combined effects of flexural fatigue cycles and freezing and thawing cycles on the flexural properties of plain and fiber reinforced concrete. Doctoral Dissertation, Nova Scotia, Canada, 2005.

7. Mailhot T, Bissonnette B, Saucier F, Pigeon M. Flexural Fatigue Behavior of Steel Fiber Reinforced Concrete Before and After Cracking. Materials and Structures 34 (2001) 351-359.

8. Qiu J, Yang EH. Micromechanics-based investigation of fatigue deterioration of engineered cementitious composite (ECC). Cement and Concrete Research 95 (2017) 65-74.

9. Lee MK., Barr BIG. An overview of the fatigue behaviour of plain and fibre reinforced concrete. Cement and Concrete Composites 26(4) (2004) 299-305.

10. Suthiwarapirak $\mathrm{P}$, Matsumoto $\mathrm{T}$, Kanda T. Multiple cracking and fiber bridging characteristics of engineered cementitious composites under fatigue flexure. Journal of materials in civil engineering 16(5) (2004) 433-443.

11. Sherir MA, Hossain K. Lachemi M. Structural performance of polymer fiber reinforced Engineered Cementitious Composites subjected to static and fatigue flexural loading. Polymers 7(7) (2015) 1299-1330.

12. Li VC, Wu C, Wang S, Ogawa A, Saito T. Interface Tailoring for Strain-hardening PVA-ECC. ACI Materials Journal 99(5) (2002) 463-472.

13. Mechtcherine V, Jun P. Stress-strain behaviour of strainhardening cement-based composites (SHCC) under repeated tensile loading. Fracture mechanics of concrete structures (2007) 1441-1448.

14. Sui L, Zhong Q, Yu K, Xing F, Li P, Zhou Y. Flexural fatigue properties of ultra-high performance engineered cementitious composites (UHP-ECC) reinforced by polymer fibers. Polymers 10(8) (2018) 892.

15. Matsumoto, T., Wangsiripaisal, K., Hayashikawa, T., \& He, $X$. Uniaxial tension-compression fatigue behavior and fiber bridging degradation of strain hardening fiber reinforced cementitious composites. International Journal of Fatigue 32(11) (2010) 1812-1822.

16. Müller, S., \& Mechtcherine, V. Fatigue behaviour of strainhardening cement-based composites (SHCC). Cement and Concrete Research 92 (2017) 75-83.

17. Yu, K., Li, L., Yu, J., Wang, Y., Ye, J., \& Xu, Q. Direct tensile properties of engineered cementitious composites: A review. Construction and Building Materials 165 (2018) 346-362.

18. Suthiwarapirak, P., Matsumoto, T., \& Kanda, T. Multiple cracking and fiber bridging characteristics of engineered cementitious composites under fatigue flexure. Journal of Materials in Civil Engineering 16(5) (2004) 433-443.

19. Alam, B. A. Fatigue performance of engineered cementitious composites, Doctoral dissertation, Middle East Technical University, 2016.

20. Yildirim, T., Keskinates, M., Godek, E., Tosun Felekoglu, K., Felekoglu, B., \& Onal, O. Strain Analysis of Multiple Cracking Fiber Reinforced Composites by Digital Image Correlation: Evaluation of Parameter Effects. Technical Journal 31(1) (2020) 9711-9731.

21. Jin Q, Li VC. Development of Lightweight Engineered Cementitious Composite for durability enhancement of tall concrete wind towers. Cement and Concrete Composites 96 (2019) 87-94.

22. Japan Society of Civil Engineers. Recommendations for Design and Construction of High Performance Fiber Reinforced Cement Composites with Multiple Fine Cracks (HPFRCC), Japan, 1-88, 2008.

23. Malek A, Scott A, Pampanin S, MacRae G, Marx S. Residual Capacity and Permeability-Based Damage Assessment of Concrete under Low-Cycle Fatigue. Journal of Materials in Civil Engineering 30(6) (2018) 04018081. 